\title{
Studies on Vitamin D Levels in Serum of HIV Infected Patients: Their Effect on Progression towards AIDS
}

\author{
Catherine Wanjiru Gichuhi ${ }^{*}$, Daniel Kariuki1 ${ }^{1}$, Andrew Nyerere'2, Malkit Riyat ${ }^{3}$ \\ ${ }^{1}$ Department of Biochemistry, Jomo Kenyatta University of Agriculture and Technology, Nairobi, Kenya \\ ${ }^{2}$ Department of Medical Microbiology, Jomo Kenyatta University of Agriculture and Technology, Nairobi, Kenya \\ ${ }^{3}$ Department of Pathology, Aga Khan University Hospital, Nairobi, Kenya \\ Email: ${ }^{*}$ cathrinegichuhi@gmail.com
}

Received 20 September 2014; revised 15 October 2014; accepted 12 November 2014

Copyright (C) 2014 by authors and Scientific Research Publishing Inc.

This work is licensed under the Creative Commons Attribution International License (CC BY).

http://creativecommons.org/licenses/by/4.0/

(c) (i) Open Access

\begin{abstract}
Vitamin D deficiency may be more prevalent among HIV-positive patients than in the general population due to HIV disease-related factors. This study examined the effects of HIV infection and use of antiretroviral drugs in serum vitamin D levels in HIV patients visiting Aga Khan University Hospital, Nairobi Kenya from October 2013 to April 2014. The effect of vitamin $D$ status on $\mathrm{CD}_{4}$ cell count and HIV viral load was evaluated to determine the status of disease progression to AIDS. HIV viral load in blood samples was determined using COBAS Ampliprep/TaqMan HIV-1 test kit while $\mathrm{CD}_{4}$ cell counts were done using the fluorescence-activated cell sorter system. The levels of vitamin $D$ in serum were determined using electrochemiluminescence binding assay in Cobas E601 mass analyzers. In addition, selected plasma enzymes were used to evaluate liver function. Higher percentage (49.12\%) of deficient vitamin D cases were observed among HIV patients not on ART. Deficient levels of Vitamin D were associated with abnormal selected liver enzymes. High viral load was observed among patients not on ART with deficient and insufficient vitamin $D$. The $\mathrm{CD}_{4}$ cell count was higher in patients on ART with sufficient vitamin D levels compared to those with deficient vitamin $D$. These observations suggest a need to supplement ART with vitamin $D$ in order to ameliorate Vitamin D deficiency as a strategy to improve HIV management.
\end{abstract}

\section{Keywords}

Vitamin D, HIV Patients, ART, Viral Load, $\mathrm{CD}_{4}$ Count

\footnotetext{
${ }^{*}$ Corresponding author.
}

How to cite this paper: Gichuhi, C.W., Kariuki, D., Nyerere, A. and Riyat, M. (2014) Studies on Vitamin D Levels in Serum of HIV Infected Patients: Their Effect on Progression towards AIDS. World Journal of AIDS, 4, 422-429. 


\section{Introduction}

Human Immunodeficiency Virus (HIV) infection is characterized by a progressive deterioration in immune function. Interventions that offset this impairment have the potential to slow HIV disease progression and improve quality of life [1]. Vitamin D may represent one such intervention because of its involvement in the human immune response. Although the mechanisms implicated are not fully understood, laboratory studies have suggested an important role of vitamin D in immune regulation; the discovery of vitamin D receptors (VDRs) on peripheral blood mononuclear cells has fuelled the interest in vitamin D as an immune modulator. More recently, vitamin $\mathrm{D}$ has been shown to have an integral role in the innate immune response to infections such as tuberculosis [2].

The relationship between vitamin D and HIV disease progression has become a topic of interest to research. A study in Norway found that HIV-infected patients with low 25-dihydroxyvitamin $\mathrm{D}_{3}$ levels, the biologically active metabolite of vitamin $\mathrm{D}$, had significantly shorter survival time than those with normal concentrations [3]. In another study in Tanzania, HIV-infected pregnant women were supplemented with multivitamins lacking vitamin D and followed up to observe pregnancy outcomes and disease progression. A correlation was drawn between reduced levels of Vitamin D and the rate of HIV disease progression to AIDS [4].

Although there is no agreement among international experts on the most appropriate cut-off value for adequate vitamin D level, individuals with 25-(OH)D below $20 \mathrm{ng} / \mathrm{ml}$ are considered as deficient [2]. However, a value above $30 \mathrm{ng} / \mathrm{ml}$ has been suggested to associate with better health outcomes such as higher bone mineral density, less falls and fractures as well as protection against cancer in the general population [2]. A low vitamin D level has recently been associated with increased mortality in the general population [5] as well as with HIV disease progression and overall mortality in a cohort of Tanzanian pregnant women with HIV infection [1].

Patients receiving anti-retroviral (ARV) therapies are at a greater risk for developing vitamin D deficiency and are at higher risk of developing bone problems than patients not taking ARV treatments [6] [7].

It has also been observed that ART may be affecting normal levels of vitamin D, parathyroid hormone (PTH), and BMD, significantly increasing risk of developing fractures [8]. Measurement of vitamin D in serum and supplementation of the vitamin in those with low levels has been widely adopted in HIV clinical practice. However, not much data on the effect of vitamin $\mathrm{D}$ on $\mathrm{CD}_{4}$ cell count and viral load is available. Also, information on the clinical benefits and cost effectiveness of vitamin D supplementation is scarce. This study therefore examined the relationship between HIV infection, ART and levels of serum vitamin D; their effects on $\mathrm{CD}_{4}$ cell count and viral load in HIV positive patients.

\section{Materials and Methods}

\subsection{Informed Consent}

All participants in the study enrolled willingly through informed consent. Participant information was handled with utmost confidentiality and all ethical clearance for the study was assented to by the Aga Khan University Hospital Scientific and Ethical Review.

\subsection{Sample Size}

118 HIV positive blood samples were evaluated during the study period. This sample size was purposively determined taking into consideration the patient presentation at the study site.

\subsection{Collection of Blood Samples}

All samples used in this study were obtained with ethical approval of the institution. Five milliliters of venous blood from consenting patients was drawn into EDTA vacutainer tube with clot activator. The samples were centrifuged in a table top high speed capacity centrifuge at $5000 \mathrm{~g}$ for 5 min to obtain serum. The plasma samples were coded and stored for further analysis. Another five milliliters was drawn into a clean EDTA (liquid) containing vacutainer tube for the analyses of $\mathrm{CD}_{4}$ cell count.

\subsection{Determination of Serum Vitamin D}

The vitamin D assay was performed using electrochemiluminescence binding assay in Cobas E601 mass ana- 
lyzer (Roche Diagnostics). The levels of vitamin D were expressed in nanograms per milliliter.

\section{5. $\mathrm{CD}_{4}$ Count}

A FACS Count fluorescence-activated cell sorter (FACS) system (Becton Dickinson) was used to enumerate absolute values for $\mathrm{CD}_{4}$ cells in unlysed whole blood containing EDTA. This blood was added to ready-to-use reagent containing tubes for the determination of the absolute counts of $\mathrm{CD}_{4}+\mathrm{T}$ lymphocytes according to the manufacturer's instructions. The $\mathrm{CD}_{4}$ was expressed in copies per milliliter $(\mathrm{cp} / \mathrm{ml})$.

\subsection{Determination of HIV-1 Viral Load}

The HIV-1 RNA in plasma was quantitated using COBAS Ampliprep/COBAS TaqMan HIV-1 test version 2.0. The samples were processed in COBAS Ampliprep system and quantitated using COBAS TaqMan analyzer. The viral load was expressed in copies per milliliter.

\subsection{Assay of Enzymes Associated with Liver Function}

Alkaline phosphatase (ALP), gamma glutamyl transferase (GGT) and Alanine amino transferase (ALT) enzymes were analysed using the enzyme calorimetric assay in accordance with the standardized method recognized by international federation of clinical chemistry (IFCC). The analysis was conducted using cobas e601 mass analyzer. The quantity of enzyme present in plasma was expressed in units per liter (units/liter).

\section{Results}

\subsection{Status of Serum Vitamin D in HIV Positive Patients}

Serum vitamin D was determined in 118 patients. Fifty seven (57) of the participants were HIV infected and not receiving antiretroviral therapy and sixty one (61) were HIV infected and receiving antiretroviral therapy. Overall, $46(39 \%)$ of the patients were vitamin D deficient ( $\leq 20 \mathrm{ng} / \mathrm{ml}), 40$ (34\%) were vitamin D insufficient (21 $29 \mathrm{ng} / \mathrm{ml})$ and $32(27 \%)$ were vitamin D sufficient $(\geq 30 \mathrm{ng} / \mathrm{ml})$. Out of the fifty seven patients not receiving treatment, 28 (49.12\%) were vitamin D deficient, 20 (35.09\%) were vitamin D insufficient and 9 (15.79\%) had vitamin D sufficient. Out of 61 patients who were on treatment 18 (29.51\%) were vitamin D deficient, 20 (32.78\%) were vitamin D insufficient and 23 (37.71\%) were vitamin D sufficient (Table 1). None of the participants were reported to have vitamin D hypervitaminosis (>74 ng/ml).

\section{2. $\mathrm{CD}_{4}$ Cell Count}

Amongst patients not on ART and vitamin D deficient $70.4 \%$ had $\mathrm{CD}_{4}$ cell count $<200 \mathrm{cp} / \mathrm{ml}, 25.9 \%$ had $\mathrm{CD}_{4}$ count between $200-499 \mathrm{cp} / \mathrm{ml}$ and $3.7 \%$ had $\mathrm{CD}_{4}$ count $\geq 500 \mathrm{cp} / \mathrm{ml}$. In patients with sufficient vitamin $\mathrm{D}$ and not on ART $44.4 \%$ of the patients had $\mathrm{CD}_{4}$ cell count $<200 \mathrm{cp} / \mathrm{ml}, 55.6 \%$ had $\mathrm{CD}_{4}$ cell count between $200-499$ $\mathrm{cp} / \mathrm{ml}$ and none of the patient had $\mathrm{CD}_{4}$ count $\geq 500$. Patient who were HIV+ART+ with deficient vitamin $\mathrm{D}$ had $44.4 \%$ of the patients with $\mathrm{CD}_{4}$ count $<200 \mathrm{cp} / \mathrm{ml}, 27.7 \%$ with $\mathrm{CD}_{4}$ cell count between $200-499 \mathrm{cp} / \mathrm{ml}$ and

Table 1. Status of vitamin D in serum of HIV positive patients.

\begin{tabular}{|c|c|c|c|c|}
\hline & \multicolumn{4}{|c|}{ Vitamin D levels } \\
\hline & & Deficient $(\geq 20 \mathrm{ng} / \mathrm{ml})$ & Insufficient (21 - 29 ng/ml) & Sufficient $(\geq 20 \mathrm{ng} / \mathrm{ml})$ \\
\hline & Total & No. (\%) of patient & & \\
\hline $\mathbf{N}$ & 118 & $46(38.98)$ & $40(33.90)$ & $32(27.11)$ \\
\hline \multicolumn{5}{|l|}{ Patient type } \\
\hline HIV positive not on ART & 57 & $28(49.12)$ & 20 (35.09) & 9 (15.79) \\
\hline HIV positive on ART & 61 & $18(29.51)$ & $20(32.78)$ & $23(37.71)$ \\
\hline
\end{tabular}

n-Number of participants. ART indicates antiretroviral therapy; HIV+ indicates HIV infected participants. Vitamin D deficiency was proportionately higher in patients who were not on ART than in patients who were on ART. 
$27.7 \%$ of the patients had $\mathrm{CD}_{4}$ count $\geq 500 \mathrm{cp} / \mathrm{ml}$ compared to patients with sufficient vitamin $\mathrm{D} 30.4 \%$ had $\mathrm{CD}_{4}$ count $<200 \mathrm{cp} / \mathrm{ml}, 26.1 \%$ had $\mathrm{CD}_{4}$ cell count between $200-499 \mathrm{cp} / \mathrm{ml}$ and $43.5 \%$ had $\mathrm{CD}_{4}$ count $\geq 500$ $\mathrm{cp} / \mathrm{ml}$ (Table 2).

\subsection{Determination of Viral Load}

HIV viral load was defined as low when the levels were $<10,000 \mathrm{cp} / \mathrm{ml}$, moderate when the levels were 10,000 $100,000 \mathrm{cp} / \mathrm{ml}$ and high when the levels were $>100,000 \mathrm{cp} / \mathrm{ml}$. In HIV patients who were not on treatment and were deficient in vitamin $\mathrm{D}$, those with low viral load contributed to $21.1 \%$, those with moderate viral load formed 31\% while those with high viral load formed $65.2 \%$. In the same group, patients with sufficient vitamin D were observed to have low viral load in $37.5 \%$, moderate viral load in $25 \%$ and high viral load in $37.5 \%$. Results obtained from HIV+ART+ showed that patients with deficient Vitamin D formed $61.1 \%$ of the patients with low viral load, $16.7 \%$ had moderate viral load and $22.2 \%$ had high viral load. Patients with sufficient vitamin D and on ART were observed to have low viral load in $77.3 \%$, moderate viral load in $4.5 \%$ and high viral load in $18.2 \%$ as shown in Table 2.

\subsection{Levels of Selected Serum Enzymes Associated with Liver Function}

In HIV+ART-, ALP levels in patients with vitamin D deficiency were normal in $25 \%$ and abnormal in $75 \%$, GGT levels were normal in $28.57 \%$ and abnormal in $71.42 \%$ and ALT levels were normal in $57.42 \%$ and abnormal in 42.85\%. Patients with sufficient vitamin D and not on ART had ALP levels normal in 8 (88.89\%) and abnormal in 1 (11.11\%). GGT levels were normal in 7 (77.78\%) and abnormal in 2 (22.28\%). ALT levels were normal in all the patients. In HIV+ART+ patients with deficient vitamin D ALP levels were normal in $72.22 \%$ and elevated in $27.78 \%$. GGT was normal in $72.22 \%$ and elevated in $27.78 \%$. ALT was normal in $88.89 \%$ and elevated in $11.11 \%$. In HIV+ART+ patients who had sufficient vitamin D levels, ALP levels were normal in $60.87 \%$ and abnormal in $39.13 \%$ patients. GGT levels were normal in $60.87 \%$ and abnormal in $39.13 \%$ patients. ALT was normal in $78.26 \%$ and abnormal in $21.74 \%$ of the patients (Table 3 ).

\section{Discussion}

The percentage of patients with sufficient vitamin D was 37.71\% in the HIV infected ART receiving group and $15.79 \%$ in the group not on ART. In contrast the percentage of patients with deficient vitamin D in the HIV+ART+ group was $29.51 \%$ and $49.12 \%$ in HIV+ART- group (Table 1 ). This suggests an influence of ART on serum levels of $25(\mathrm{OH}) \mathrm{D}$ and $1,25(\mathrm{OH})_{2} \mathrm{D}$. Experimental studies have suggested an inhibitory effect of

Table 2. Distribution of $\mathrm{CD}_{4}$ cell count and HIV viral load in patients with deficient, insufficient and sufficient vitamin D levels, on ART and not on ART.

\begin{tabular}{|c|c|c|c|c|c|c|}
\hline & \multicolumn{3}{|c|}{$\mathrm{HIV}+\mathrm{ART}-$} & \multicolumn{3}{|c|}{$\mathrm{HIV}+\mathrm{ART}+$} \\
\hline & \multicolumn{6}{|c|}{ Vitamin D levels } \\
\hline & Deficient & Insufficient & Sufficient & Deficient & Insufficient & Sufficient \\
\hline $\mathrm{CD}_{4} \mathrm{~T}$ cell category $(\mathrm{cp} / \mathrm{ml})$ & \multicolumn{6}{|c|}{ No. (\% of patients) } \\
\hline$<200$ & $19(70.4)$ & $9(50)$ & $4(44.4)$ & $8(44.4)$ & $6(30)$ & $7(30.4)$ \\
\hline $200-499$ & 7 (25.9) & 7 (38.9) & $5(55.6)$ & $5(27.7)$ & $7(35)$ & $6(26.1)$ \\
\hline$\geq 500$ & $1(3.7)$ & $2(11.1)$ & $0(0)$ & $5(27.7)$ & 7 (35) & $10(43.5)$ \\
\hline \multicolumn{7}{|l|}{ HIV viral load (cp/ml) } \\
\hline$<10,000$ & $5(21.7)$ & $2(13.3)$ & $3(37.5)$ & $11(61.1)$ & $13(65)$ & $17(77.3)$ \\
\hline $10,000-100,000$ & $3(13)$ & $3(20)$ & $2(25)$ & $3(16.7)$ & $2(10)$ & $1(4.5)$ \\
\hline$>100,000$ & $15(65.2)$ & $10(66.7)$ & $3(37.5)$ & $4(22.2)$ & $5(25)$ & $4(18.2)$ \\
\hline
\end{tabular}

High percentage of HIV positive patients with deficient vitamin D had low $\mathrm{CD}_{4}$ cell count with high viral load. 
Table 3. Levels of selected enzymes in serum HIV positive patients not on ART and on ART.

\begin{tabular}{|c|c|c|c|c|c|c|c|}
\hline \multirow[b]{2}{*}{ Vitamin D levels } & & \multicolumn{3}{|c|}{ HIV+ not on ART } & \multicolumn{3}{|c|}{$\mathrm{HIV}+$ on ART } \\
\hline & & Deficient & Insufficient & Sufficient & Deficient & Insufficient & Sufficient \\
\hline $\begin{array}{l}\text { Serum enzymes associated } \\
\text { with liver function }\end{array}$ & & \multicolumn{6}{|c|}{ No. (\% of patients) } \\
\hline \multirow{2}{*}{$\begin{array}{l}\text { Alkaline phosphatase } \\
\text { (units/l) }\end{array}$} & $\mathrm{N}$ & $7(25)$ & 14 (73.68) & 8 (88.89) & $13(72.22)$ & $18(100)$ & $14(60.87)$ \\
\hline & A & $21(75)$ & $5(26.32)$ & $1(11.11)$ & $5(27.78)$ & $0(0)$ & 9 (39.13) \\
\hline \multirow{2}{*}{$\begin{array}{l}\text { Gamma glutamyl } \\
\text { transferase (units/l) }\end{array}$} & $\mathrm{N}$ & $8(28.57)$ & 12 (63.16) & 7 (77.78) & $13(72.22)$ & 11 (61.11) & $14(60.87)$ \\
\hline & A & $20(71.42)$ & $7(36.84)$ & $2(22.22)$ & $5(27.78)$ & 7 (38.89) & 9 (39.13) \\
\hline \multirow{2}{*}{$\begin{array}{l}\text { Alanine amino transferase } \\
\text { (units/l) }\end{array}$} & $\mathrm{N}$ & $16(57.42)$ & 17 (89.47) & $9(100)$ & 16 (88.89) & 17 (94.44) & $18(78.26)$ \\
\hline & A & $12(42.85)$ & $2(10.53)$ & $0(0)$ & $2(11.11)$ & $1(5.56)$ & 5 (21.74) \\
\hline
\end{tabular}

N-Normal levels; A-Abnormal levels; High percentages of Patients with deficient vitamin D were found to have altered levels of serum enzymes associated with the liver compared to those with sufficient vitamin D.

protease inhibitors on $25(\mathrm{OH}) \mathrm{D}$ and $1,25(\mathrm{OH})_{2}$ D synthesis and some cross-sectional studies have found HAART to be associated with lower 25(OH) D while others have found higher 25(OH) D. One such study has shown an association between efavirenz, but not other antiretroviral medication was associated with vitamin D deficiency [9]. Another study showed that efavirenz and zidovudine were associated with vitamin D deficiency. In addition the study participants showed an increase in vitamin D levels when they were changed to a regime boosted with aarunavil with greatest increase among patients changed from efavirenz or zidovudine [10]. The mechanism of efavirenz effect on vitamin D has been linked to induction of Cytochrome P450 like CYP24 which converts both $25(\mathrm{OH})$ vitamin $\mathrm{D}$ and the active form of vitamin $\mathrm{D}, 1,25(\mathrm{OH})$ vitamin $\mathrm{D}$ to inactive metabolites [11] Efavirenz has been observed to reduce the expression of Cytochrome CYP2R1 which hydroxylates $\mathrm{D}_{3}$ and $\mathrm{D}_{2}$ necessary for vitamin $\mathrm{D}$ activation [12]. Another study has shown tenofovir to be associated with higher levels of 25(OH) D as it causes proximal tubule injury, inducing renal dysfunction [13] [14]. Given that conversion of $25(\mathrm{OH}) \mathrm{D}$ to $1,25(\mathrm{OH})_{2}$ D by $1 \alpha$ hydroxylase occurs primarily in the proximal tubule, tenofovir-induced proximal tubule dysfunction might also reduce hydroxylation of $25(\mathrm{OH}) \mathrm{D}$ leading to normal levels of 25(OH) D and abnormal levels of 1,25(OH $)_{2}$ D.

High $\mathrm{CD}_{4}$ counts $(\geq 500 \mathrm{cp} / \mathrm{ml})$ were observed in $36.07 \%$ of patients on ART which was more than in patients not on ART (5.56\%). The latter had $40.74 \%$ of the patients with $\mathrm{CD}_{4}$ count $\leq 200 \mathrm{cp} / \mathrm{ml}$. levels of serum vitamin D seemed to have an effect on the counts of $\mathrm{CD}_{4}$ in that $43.5 \%$ of patients with sufficient vitamin D levels and on ART had high $\mathrm{CD}_{4}$ count whereas $44.4 \%$ of those with deficient vitamin $\mathrm{D}$ had low $\mathrm{CD}_{4}$ count $(\leq 200 \mathrm{cp} / \mathrm{ml})$. this was also observed in patients not on ART. This strongly suggests that vitamin D levels to a greater extent boosts the $\mathrm{CD}_{4}$ cell counts in both patients on ART and those not on ART. This is in agreement with the findings of Ross et al, de Luis et al. and Kim et al. who found a positive association between vitamin D with $\mathrm{CD}_{4}$ count [15]-[17].

The viral load was observed to be significantly higher in patients who were not on ART than in patients who were on ART, with majority of the former having viral loads of $>100,000 \mathrm{cp} / \mathrm{ml}$ and majority of the latter having viral loads of $<10,000 \mathrm{cp} / \mathrm{ml}$ (Table 2). For both groups of patients, a high percentage of patients with sufficient vitamin D levels (37.5\% for HIV+ART- and $77.3 \%$ for HIV+ART+) were observed to have low viral loads. A high percentage of patients with deficient vitamin D levels in patients not on ART were observed to have high viral load that is $65.2 \%$. Our observations suggest possible role of vitamin D together with ART in lessening the viral load. The role of vitamin D could be explained in the activation of cathelicidin, an antimicrobial peptide found in the lysosomes of macrophages and the secondary granules of neutrophils and can be produced by epithelial cells [18] [19]. Vitamin D up regulates genetic expression of cathelicidin which exhibits broad spectrum microbicidal activity against bacteria, Fungi and viruses [20] In humans only one cathelicidin LL-37 has been identified. Studies have demonstrated that LL-37 has anti-HIV activities with 50\% effective concentration for inhibition of viral replication [21] [22]. This may explain why patients with low vitamin D levels were found to have a high viral load. This is consistent with the findings of Kim et al. who found that detectable high viremia 
was significantly associated with vitamin D deficiency [17].

The effect of vitamin D on progression towards AIDs may be explained by its role in innate and adaptive immunity. The innate immune system is the first line of defense against infections and comprises of innate immune cells like the natural killer cells that have the ability to destroy cells infected by viruses. The innate immune system also recruits immune cells to the sites of infection through the production of cytokines by dendritic cells. Studies have linked low levels of vitamin D with increased infection. A cross sectional study involving 19,000 subjects conducted showed that individuals with low vitamin D levels $(<30 \mathrm{ng} / \mathrm{ml})$ were more likely to have an upper respiratory tract infection than those with sufficient levels [23]. Another cross sectional study in Finland involving military recruits showed that those with high vitamin D levels were found to be off duty less days due to upper respiratory tract infections than recruits with low vitamin D levels [24].

Few studies on vitamin D status in HIV related health effects have been conducted but a recent study [25] on the relationship between vitamin D, lipids, HIV infection and HIV treatment showed that total serum 25(OH) D was high in the HIV infected ART treated group compared to untreated HIV group. This is consistent with our findings with the untreated group having low levels of vitamin D (mean $20.181 \mathrm{ng} / \mathrm{ml}$ ) compared to the treated group (mean $27.619 \mathrm{ng} / \mathrm{ml}$ ). Mehta et al reported that progression to HIV disease stage three as defined by the WHO, was significantly associated with low vitamin D levels. He also reported that low vitamin D levels pose higher risk of developing severe anemia in pregnant women [1] These studies show that vitamin D has a role in HIV disease progression probably linked to its role in innate immunity where it has been shown to improve phagocytic capacity of macrophages, cell mediated immunity and increase natural killer cell number and cytolytic activity. Rook et al. reported that hydroxylated metabolites of vitamin $\mathrm{D}_{3}$ can cause inhibition of the growth of Mycobacterium tuberculosis (M. tuberculosis) in normal human monocytes [26]. This could explain why vitamin D could be used to prevent progression towards AIDS as M. tuberculosis is one of the leading causes of disease progression and mortality in HIV infected patients and increased resistance to tuberculosis could potentially prolong survival in these patients.

In patients not on ART and with sufficient vitamin D, 88.89\% cases were found to have normal levels of serum Alkaline phosphatase, $77.78 \%$ had normal gamma Glutamyl transferase and all the patients had normal Alanine amino transferase while those with deficient levels of vitamin D were observed to strongly associate with abnormal levels of these enzymes in serum with 75\% having abnormal ALP, 71.42\% with abnormal GGT and $42.85 \%$ with abnormal ALT. This shows that sufficient vitamin D levels in serum associate with high incidence of normal enzymes while deficient levels of vitamin D were observed to strongly associate with abnormal levels of these enzymes in serum. However, this trend was not observed for patients on ART with relatively lower percentages of patients with abnormal levels of these enzymes being observed in this group of patients. This may be explained by the involvement of the liver in vitamin D metabolism given that hydroxylation of vitamin D occurs in the liver and damage to the liver during HIV infection may result in low levels of vitamin D Our study agrees with the findings of a study in Mexico which showed a moderately strong positive correlation between elevated transaminases and HIV RNA in individuals not receiving ART and without viral hepatitis co-infection [27] Consistent with reports from a study in North America [28]. For low and middle income countries, it has been demonstrated that use of ART in individuals with low $\mathrm{CD}_{4}$ count was associated with a reduced risk of hospitalization for liver related complications [29]. This findings need to be investigated further to determine the causes of the serum enzymes abnormalities in HIV infected patients.

The study also had several limitations. First 25(OH) D was measured at a single time point and we are unable to determine whether deficient vitamin D levels at a single time point or long term deficiency is biologically relevant. Secondly the results of this study were only done in a single hospital and this result may not be generalized to other HIV infected populations and therefore a study including other centres should be conducted to confirm these results. Thirdly neither the daily intake of vitamin D and calcium nor other lifestyle factors such as smoking which could affect vitamin D levels were assessed.

\section{Conclusion}

High percentages of cases with vitamin D deficiency were observed in HIV-positive patients that were not on ART. A direct positive association is also observed between levels of serum Vitamin D levels with HIV viral load and this suggests that maintenance of sufficient levels of vitamin D in HIV patients along with ART is important in maintenance of high $\mathrm{CD}_{4}$ cell counts and low viral load. Similarly, low indications of liver dysfunc- 
tion were observed in patients with sufficient vitamin D levels more so for those patients on ART. Introduction of Vitamin D supplements with ART should be considered and evaluated in the management strategies for HIV.

\section{Acknowledgements}

The authors acknowledge the Department of Pathology of the Aga Khan University Hospital, Nairobi and Jomo Kenyatta University of Agriculture and Technology for facilitating the study.

\section{References}

[1] Mehta, S., Giovannucci, E., Mugusi, M., Spiegelman, D., Aboud, S., Hertzmark, E., et al. (2010) Vitamin D Status of HIV-Infected Women and Its Association with HIV Disease Progression, Anemia, and Mortality. PLOS ONE, 5, e8770. http://dx.doi.org/10.1371/journal.pone.0008770

[2] Holick, M.F. (2007) Vitamin D Deficiency. New England Journal of Medicine, 357, 266-281. http://dx.doi.org/10.1056/NEJMra070553

[3] Haug, C., Muller, F., Aukrust, P. and Froland, S.S. (1994) Subnormal Serum Concentration of 1, 25-Vitamin D in Human Immunodeficiency Virus Infection: Correlation with Degree of Immune Deficiency and Survival. Journal of Infectious Diseases, 169, 889-893. http://dx.doi.org/10.1093/infdis/169.4.889

[4] Fawzi, W.W., Msamanga, G.I., Spiegelman, D., Wei, R. and Kapiga, S. (2004) A Randomized Trial of Multivitamin Supplements and HIV Disease Progression and Mortality. New England Journal of Medicine, 351, 23-32. http://dx.doi.org/10.1056/NEJMoa040541

[5] Melamed, M.L., Michos, E.D., Post, W. and Astor, B. (2008) 25-Hydroxyvitamin D Levels and the Risk of Mortality in the General Population. Archives of Internal Medicine, 168, 1629-1637. http://dx.doi.org/10.1001/archinte.168.15.1629

[6] Van Den Bout Van Den Beukel, C.J., Fievez, L., Michels, M., Sweep, F.C., Hermus, A.R., Bosch, M.E., et al. (2008) Vitamin D Deficiency among HIV Type 1-Infected Individuals in the Netherlands: Effects of Antiretroviral Therapy. AIDS Research and Human Retroviruses, 24, 1375-1382. http://dx.doi.org/10.1089/aid.2008.0058

[7] Yin, M. and Stein, E. (2011) The Effect of Antiretrovirals on Vitamin D. Clinical Infectious Diseases, 52, $406-408$. http://dx.doi.org/10.1093/cid/ciq169

[8] Childs, K., Welz, T., Samarawickrama, A. and Post, F.A. (2012) Effects of Vitamin D Deficiency and Combination Antiretroviral Therapy on Bone in HIV-Positive Patients. AIDS, 26, 253-262. http://dx.doi.org/10.1097/QAD.0b013e32834f324b

[9] Allavena, C., Delpierre, C., Cuzin, L., Rey, D., Viget, N., et al. (2012) High Frequency of Vitamin D Deficiency in HIV-Infected Patients: Effects of HIV-Related Factors and Antiretroviral Drugs. Journal of Antimicrobial Chemotherapy, 67, 2222-2230. http://dx.doi.org/10.1093/jac/dks176

[10] Fox, J., Peters, B., Prakash, M., Arribas, J., Hill, A., et al. (2011) Improvement in Vitamin D Deficiency Following Antiretroviral Regime Change: Results from the MONET Trial. AIDS Research and Human Retroviruses, 27, $29-34$. http://dx.doi.org/10.1089/aid.2010.0081

[11] Cheng, J.B., Levine, M.A., Bell, N.H., Mangelsdorf, D.J. and Russell, D.W. (2004) Genetic Evidence That the Human CYP2R1 Enzyme Is a Key Vitamin D 25-Hydroxylase. Proceedings of the National Academy of Sciences of the USA, 101, 7711-7715. http://dx.doi.org/10.1073/pnas.0402490101

[12] Zhou, C., Assem, M., Tay, J.C., Watkins, P.B., Blumberg, B., et al. (2006) Steroid and Xenobiotic Receptor and Vitamin D Receptor Crosstalk Mediates CYP24 Expression and Drug-Induced Osteomalacia. Journal of Clinical Investigation, 116, 1703-1712. http://dx.doi.org/10.1172/JCI27793

[13] Woodward, C., Hall, A., William, I., et al. (2009) Tenofovir-Associated Renal and Bone Toxicity. HIV Medication, 10, 482-487. http://dx.doi.org/10.1111/j.1468-1293.2009.00716.x

[14] Peyriere, H., Reynes, J., Rouanet, I., et al. (2004) Renal Tubular Dysfunction Associated with Tenofovir Therapy. Journal of Acquired Immune Deficiency Syndromes, 35, 269-273. http://dx.doi.org/10.1097/00126334-200403010-00007

[15] Allison, C.R., Suzanne, J., Meena, K., Corrynn, H., Norma, S., Daniella, L.T. and Grace, A.M. (2011) Vitamin D Linked to Carotid Intima-Media Thickness and Immune Reconstitution in HIV-Positive Individuals. Antiviral Therapy, 16, 555-563. http://dx.doi.org/10.3851/IMP1784

[16] de Luis, D.A., Bachiller, P., Aller, R., et al. (2002) Relation among Micronutrient Intakes with CD4 Count in HIV Infected Patients. Nutricion Hospitalaria, 17, 285-289.

[17] Kim, J.H., Gandhi, V., Psevdos Jr., G., Espinoza, F., Park, J. and Sharp, V. (2011) Evaluation of Vitamin D Levels 
among HIV-Infected Patients in New York City. AIDS Research and Human Retroviruses, 28, 235-241. http://dx.doi.org/10.1089/aid.2011.0040

[18] Zanetti, M. (2004) Cathelicidins, Multifunctional Peptides of the Innate Immunity. Journal of Leukocyte Biology, 75, 39-48. http://dx.doi.org/10.1189/jlb.0403147

[19] Zhang, Y., Shi, W., Tang, S., Li, J., Yin, S., Gao, X., Wang, L., Zou, L., Zhao, J., Huang, Y., Shan, L., Gounni, A.S., Wu, Y., Yuan, F. and Zhang, J. (2013) The Influence of Cathelicidin LL37 in Human Anti-Neutrophils Cytoplasmic Antibody (ANCA)-Associated Vasculitis. Arthritis Research Therapy, 15, R161. http://dx.doi.org/10.1186/ar4344

[20] Heilborn, J.D., Nilsson, M.F., Chamorro Jimenez, C.I., Sandstedt, B., Borregaard, N., Tham, E., Sørensen, O.E., Weber, G. and Ståhle, M. (2005) Antimicrobial Protein hCAP18/ LL-37 Is Highly Expressed in Breast Cancer and Is a Putative Growth Factor for Epithelial Cells. International Journal of Cancer, 114, 713-719. http://dx.doi.org/10.1002/ijc.20795

[21] Wang, G., Watson, K.M. and Buckheit Jr., R.W. (2008) Anti-Human Immunodeficiency Virus Type 1 Activities of Antimicrobial Peptides Derived from Human and Bovine Cathelicidins. Antimicrobial Agents and Chemotherapy, 52, 3438-3440. http://dx.doi.org/10.1128/AAC.00452-08

[22] Bergman, N., Moraes, K., Anderson, J., Zaric, B., Kambach, C., Schneider, R., et al. (2007) Lsm Proteins Bind and Stabilize RNAs Containing 5’ Poly(A) Tracts. Nature Structural Molecular Biology, 14, 824-831. http://dx.doi.org/10.1038/nsmb1287

[23] Ginde, A.A., Mansbach, J.M. and Camargo Jr., C.A. (2009) Association between Serum 25-Hydroxyvitamin D Level and Upper Respiratory Tract Infection in the Third National Health and Nutrition Examination Survey. Archives of Internal Medicine, 169, 384-390. http://dx.doi.org/10.1001/archinternmed.2008.560

[24] Laaksi, I., Ruohola, J.P., Tuohimaa, P., Auvinen, A., Haataja, R., Pihlajamäki, H. and Ylikomi, T. (2007) An Association of Serum Vitamin D Concentrations $<40 \mathrm{nmol} / \mathrm{L}$ with Acute Respiratory Tract Infection in Young Finnish Men. The American Journal of Clinical Nutrition, 86, 714-717.

[25] Schwartz, J.B., Moore, K.L., Yin, M., Sharma, A., Merenstein, D., Islam, T., Golub, E.T., Tien, P.C. and Adeyemi, O.M. (2014) Study of HIV-Infected and Uninfected Women in the United States Relationship of Vitamin D, HIV, HIV Treatment, and Lipid Levels in the Women's Interagency HIV. JIAPAC, 13, 250.

[26] Rook, G.A., Steele, J., Fraher, L., Barler, S., Karmali, R., O’Riordan, J. and Stanford, J. (1986) Vitamin D3, Gamma Interferon, and Control of Proliferation of Mycobacterium tuberculosis by Human Monocytes. Immunology, 57, 159163.

[27] Mata, M.J., Gaytán, M.J., Grados-Chavarría, B.H., Fuentes-Allen, J.L., Arroyo-Anduiza, C.I. and Alfaro-Mejía, A. (2009) Correlation between HIV Viral load and Aminotransferases as Liver Damage Markers in HIV Infected Naive Patients: A Concordance Cross-Sectional Study. Virology Journal, 6, 181. http://dx.doi.org/10.1186/1743-422X-6-181

[28] Dalla, P.M., Amorosa, V.K., Localio, R., Kostman, J.R. and Lo Re, V. (2010) Prevalence and Risk Factors for Significant Liver Fibrosis among HIV-Monoinfected Patients. BMC Infectious Diseases, 10, 116. http://dx.doi.org/10.1186/1471-2334-10-116

[29] Crum, C.N., Grandits, G., Echols, S., Ganesan, A., Landrum, M., Weintrob, A., Barthel, R. and Agan, B. (2010) Trends and Causes of Hospitalizations among HIV-Infected Persons during the Late HAART Era: What Is the Impact of CD4 Counts and HAART Use? Journal of Acquired Immune Deficiency Syndromes, 54, 248-257.

http://dx.doi.org/10.1097/QAI.0b013e3181c8ef22 
Scientific Research Publishing (SCIRP) is one of the largest Open Access journal publishers. It is currently publishing more than 200 open access, online, peer-reviewed journals covering a wide range of academic disciplines. SCIRP serves the worldwide academic communities and contributes to the progress and application of science with its publication.

Other selected journals from SCIRP are listed as below. Submit your manuscript to us via either submit@scirp.org or Online Submission Portal.
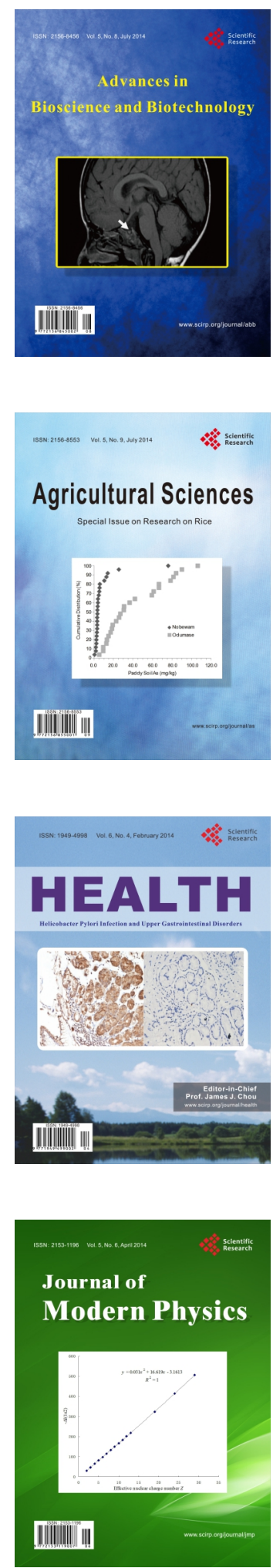
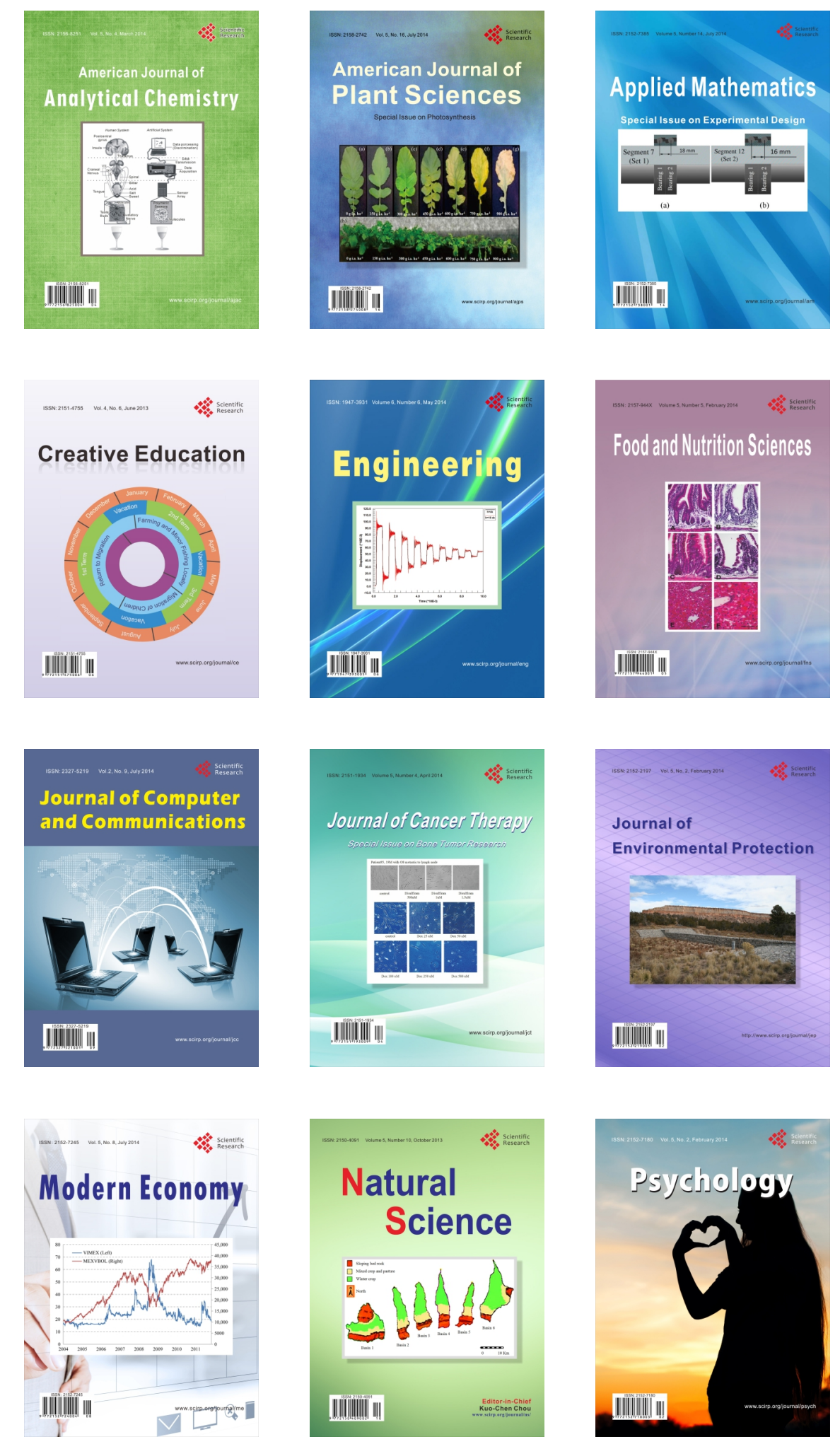